\title{
Blood and Urine Cadmium Levels in Relation to Demographic and Life Style in Middle Aged and Elderly Men
}

Y. C. Chen, ${ }^{1}$ Y. S. Pu, ${ }^{2}$ R. S. Lin, ${ }^{3}$ C. Y. Yang, ${ }^{4}$ M. K. Lai, ${ }^{2}$ S. H. Liu, ${ }^{5}$

F.-C. Sung ${ }^{1}$

1 Institute of Environmental Health, National Taiwan University, 1-1 Jen-Ai Road, Taipai, Taiwan, 100

2 Department of Urology, National Taiwan University, Taipai, Taiwan, 100

3 Institute of Epidemiology, National Taiwan University, Taipei, Taiwan, 100

4 Kaohsiung Medical University School of Public Health, Kaohsiung, Taiwan, 807

5 Department of Public Health, National Defense University, Taipei, Taiwan, 100

Received: 9 July 2000/Accepted: 18 December 2000

Background levels of cadmium in food, water, and ambient air may not be a health concern for the general population except for smoking individuals or individuals in industry producing or using cadmium. Chronic exposures, however, can be a major concern because cadmium has a tendency to accumulate, primarily in the kidneys and the liver and affect primarily the kidneys, cardiovascular system, and skeletal system (Waalkes and Rehm 1994; Järup et al. 1998). Cadmium also has been associated with an increased frequency of prostate carcinoma (Lee and White 1980; Pearce et al. 1987; Elghamy et al. 1990; Järup et al. 1998).

The incidence of prostate carcinoma has become the most frequently diagnosed cancer for men in some Western countries (American cancer Society 1999; Black et al. 1997; Haas and Sakr 1997). But, a low rate of prostate carcinoma occurs among Asians (Sung et al. 1999). This disease accounted for only $2.2 \%$ of all cancer deaths in Taiwan versus 14\% among American men's in 1995. Potential risk factors for the disease include environmental and life-style factors. Among these factors, cadmium's association was less conclusive (Järup et al. 1998).

Given that the occurrence of prostate carcinoma has an association with the exposure to cadmium, and the great difference in the incidence of the disease between Asian men and Western men, there may be a difference between them in cadmium burden. Few investigations have been conducted to measure the cadmium level in Asian populations. This study was to assess the levels of blood cadmium (BCd) and urine cadmium (UCd) of selected men aged 50 and above who live in northern Taiwan and identify factors that may have an association with the cadmium burden. This would allow us to establish baseline knowledge of human cadmium exposure for a further study in the relationship between prostate cancer and cadmium exposure.

\section{MATERIALS AND METHODS}

This investigation was conducted at a health examination center. This center has been established since 1994 to deliver clinical preventive services for routine health examinations. Urine and blood specimens are collected to routinely determine levels of creatinine, uric acid, nitrite, serum triglycerides, serum total 
cholesterol, low density lipoprotein cholesterol, high density lipoprotein cholesterol, blood calcium and iron, liver function, renal function and diabetes screening. However, cadmium exposure is not routinely assessed.

We restricted the study population to man aged 50 and above, and selected them as convenience samples from June to September 1999. We explained the purpose of the study to male clients and invited whoever was eligible in age criteria. With consent, specimens for cadmium measures were collected while they were at the health examination center, in addition to specimens collected for the routine screening examinations. Each participant completed also a self-reported questionnaire to provide personal information such as demographic characteristics, lifestyle factors, dietary characteristics and limited personal and family histories of health.

Urine was convenient to be collected in a sterile, plastic collection cup and transferred the required $10 \mathrm{ml}$ sample to a conical-bottom plastic tube free of cadmium contamination. Blood specimens of $2-3 \mathrm{ml}$ were collected in pre-screened heparin tubes also from lots verified to be free of cadmium contamination. Both urine and blood specimens were stored at $4^{\circ} \mathrm{C}$ if analyzed in a week, or at $-20^{\circ} \mathrm{C}$ if not analyzed within a week. At the analyses, $100 \mathrm{ul}$ of blood and 900ul of matrix modifier $(0.2 \%$ nitric acid, $0.5 \%$ Triton $\AA-x-100$ and $\left.0.2 \%\left(\mathrm{NH}_{4}\right)_{2} \quad \mathrm{HPO}_{4}\right)$ and $100 \mathrm{ul}$ of urine and $200 \mathrm{ul}$ of matrix modifier were prepared for analyses. Samples, quality control specimens, and standards prepared with matrix modifier were analyzed for cadmium on a Perkin-Elmer Model 5100 PC atomic absorption spectrometer with Zeeman background correction (Sampson, 1999; Sharma et al 1982). For quality control, blood reference samples (NYCOMED PHARMA AS, Oslo, Norway) were used. Urine cadmium analysis was verified every other month using Inter-laboratory Comparison program, Le Centre de toxicologie du Québec (Sainte-Foy, QC, Canada). The recovery rates for spike tests were $100.7 \pm 3.5 \%$ for urine analysis and $100.9 \pm 3.6 \%$ for blood analysis.

The data analysis was conducted with SAS 6.12 (Cary, NC) beginning with descriptive analysis of demographic and lifestyle variables of the participants. Classical statistical parameters, including mean and standard deviation, geometric mean (GM) and standard deviation, median and range, were computed for cadmium levels in the specimens. We also used multivariate logistic regression model to identify risk factors of elevated cadmium levels.

\section{RESULTS AND DISCUSSION}

We considered age as an important factor influencing cadmium burden in human and education, occupation, diet and lifestyle as other potential risk factors. Because the study participants practice annual routine health examination, it is not surprising that about $22 \%$ participants received college or graduate education. Younger individuals (ages 50-59) were more likely to work as white-collar employees than older men. (Table 1) Among individuals ages 70 and above, 
Table 1. The demographic characteristics of study participants by age

\begin{tabular}{|c|c|c|c|c|}
\hline \multirow[b]{2}{*}{ Characteristics } & \multicolumn{3}{|c|}{ Age (years) } & \multirow{3}{*}{$\begin{array}{l}\text { Total } \\
N=295\end{array}$} \\
\hline & $50-59$ & $60-69$ & $70+$ & \\
\hline & $\mathrm{N}=144$ & $\mathrm{~N}=105$ & $N=46$ & \\
\hline & $N(\%)$ & $n(\%)$ & $\mathrm{n}(\%)$ & $n(\%)$ \\
\hline \multicolumn{5}{|l|}{ Education (Years) } \\
\hline$\leqq 9$ & $61(42.4)$ & $61(58.1)$ & $21(45.7)$ & $143(48.5)$ \\
\hline $10-15$ & $42(29.2)$ & $27(25.7)$ & $14(30.4)$ & $83(28.1)$ \\
\hline$>15$ & $39(27.0)$ & $15(14.3)$ & $10(21.7)$ & $64(21.7)$ \\
\hline Missing & $2(1.4)$ & $2(1.9)$ & $1(2.2)$ & $5(1.7)$ \\
\hline p-value* & & & & 0.09 \\
\hline \multicolumn{5}{|l|}{ Occupation } \\
\hline White collar & $94(65.3)$ & $48(45.7)$ & $14(30.4)$ & $156(52.9)$ \\
\hline Blue collar & $33(22.9)$ & $29(27.6)$ & $5(10.9)$ & $67(22.7)$ \\
\hline None & $12(8.3)$ & $27(25.7)$ & $23(50.0)$ & $62(21.0)$ \\
\hline Missing & $6(4.2)$ & $1(0.9)$ & $3(6.5)$ & $10(3.4)$ \\
\hline p-value* & & & & 0.001 \\
\hline \multicolumn{5}{|l|}{ Smoking } \\
\hline No & $73(50.7)$ & $48(45.7)$ & $46(39.1)$ & $139(47.1)$ \\
\hline Quit $>5$ years & $15(10.4)$ & $16(14.4)$ & $14(30.4)$ & $45(15.3)$ \\
\hline Quit $\leqq 5$ years & $12(8.3)$ & $12(10.6)$ & $3(6.5)$ & $27(9.1)$ \\
\hline Yes & $43(29.9)$ & $28(26.7)$ & $11(23.9)$ & $82(27.8)$ \\
\hline Missing & $1(0.7)$ & $1(0.9)$ & $0(0.0)$ & $2(0.7)$ \\
\hline p-value* & & & & 0.01 \\
\hline \multicolumn{5}{|l|}{ Alcohol } \\
\hline No & $86(57.6)$ & $57(54.3)$ & $31(67.4)$ & $174(60.0)$ \\
\hline Quit & $8(5.5)$ & $12(11.4)$ & $5(10.9)$ & $25(8.5)$ \\
\hline Yes & $47(32.6)$ & $32(30.5)$ & $10(21.7)$ & $89(30.2)$ \\
\hline Missing & $3(2.1)$ & $4(3.8)$ & $0(0.0)$ & $7(2.4)$ \\
\hline p-value* & & & & 0.28 \\
\hline
\end{tabular}

*p-value of Chi-square test

$41.3 \%$ of them remained active at work. They were less likely than younger ones to be current smokers $(39.1 \%$ vs. $50.7 \%)$, but more likely to have quit the smoking habit longer than 5 years. Apparently, lifestyles of study participants varied among age groups. Although, drinking habit did not vary substantially among men of these age groups. 
Both arithmetic and geometric means showed $\mathrm{BCd}$ and $\mathrm{UCd}$ levels of study subjects tended to increase as age increased, although trends were not significant in the Wilcoxon rank-sum test (Table 2). Geometric means show that the $\mathrm{BCd}$ levels increased from $0.78 \mathrm{ug} / \mathrm{L}$ for younger individuals to $0.93 \mathrm{ug} / \mathrm{L}$ for the oldest individuals. The values of $\mathrm{UCd}$ for the corresponding groups were 0.74 $\mathrm{ug} / \mathrm{g}$ creatinine and $0.92 \mathrm{ug} / \mathrm{g}$ creatinine. The overall geometric means were 0.83 $\mathrm{ug} / 1$ for $\mathrm{BCd}$ and $0.82 \mathrm{ug} / \mathrm{g}$ creatinine for UCd. Cadmium levels in blood for normal population are usually between $0.1 \mathrm{ug} / \mathrm{L}$ and $1.0 \mathrm{ug} / \mathrm{L}$ for nonsmoker and 1.0-4.0 ug/L for smokers (Sharma, 1982; Järup, et al. 1998). Our study population seemed to have the BCd levels similar to Italian (dell'Omo et al. 1999), but might have slight higher UCd level than American (Paschal et al. 2000).

Some other chemicals may influence the body burden of cadmium. A low intake of dietary calcium, iron, zinc, and copper may account for increased susceptibility to bone effect at cadmium exposure (Klaassen, 1996). Flanagan (1978) also found iron deficiency increases the cadmium absorption in the gastrointestinal tract. Table 2 also shows blood iron levels decreased as age increased, indicating a negative association with cadmium burden. The levels in blood calcium did not vary substantially.

If not by inhalation exposure in the workplace, food and cigarette smoke are the largest sources of cadmium exposure for general population (Järup et al. 1998). Cadmium from cigarette smoke is in very small size of particles and consequently $50-100 \%$ are deposited in the alveoli (Nordberg, 1985). Cigarette smoke inhalation is thus the largest source of cadmium exposure. This study also found that $\mathrm{BCd}$ level was higher in smokers than in nonsmokers $(1.09 \mathrm{ug} / \mathrm{L}$ vs. 0.73 $\mathrm{ug} / \mathrm{L}$ in GM) (Table 3). The level for those who had quit the habit for less than 5 years was similar to that for current smokers. Current alcohol drinking also elevated the $\mathrm{BCd}$ level. Blue-collar employees had higher $\mathrm{BCd}$ levels probably due to occupational exposure. It is also possible that blue-collar employees are more likely smokers (Yen, et al.1994). Further analyses also showed that subjects who had received less education were more likely smokers and blue-collar employees (data not shown). Therefore, it is not surprising that study participants receiving 9 years or less education had the highest levels of $\mathrm{BCd}(\mathrm{GM}=0.96 \mathrm{ug} / \mathrm{L})$ and $\mathrm{UCd}(\mathrm{GM}=0.91 \mathrm{ug} / \mathrm{g}$ cre.). Those with 16 years and above of education had the lowest levels of BCd (GM=0.69 ug/L) and $\mathrm{UCd}(\mathrm{GM}=0.70 \mathrm{ug} / \mathrm{g}$ cre .). Current smokers also had a higher UCd level, except former smokers, who had the lowest level in urine. UCd levels reflect most total body burden of cadmium and part of recent exposure (Bernard and Lauwerys, 1986). On the other hand, BCd levels indicate principally the recent exposure to cadmium (Lauwerys et al. 1994; Roels et al. 1989).

Based on the data, half of participants in this study had their BCd at the level of $0.84 \mathrm{ug} / \mathrm{L}$ or higher, and one fourth of subjects had UCd at the level of $1.73 \mathrm{ug} / \mathrm{g}$ creatinine or higher. Table 4 shows multivariate logistic regression model identifying factors associated with elevated levels of $\mathrm{BCd}$ and $\mathrm{UCd}$. Cadmium levels did not associate substantially with occupation, alcohol consumption, blood iron and shellfish consumption. Compared with men aged 50-59 years, the odds 
ratios of higher UCd level were 2.0 for men aged 60-69, and 3.4 for men aged 70 and above. There was also a similar trend by age in the relationship with elevated $\mathrm{BCd}$, but with the evidence of less strong. This phenomenon may reflect that recent exposure to cadmium is not associated with age significantly, but the total body burden is significantly age associated. This finding is consistent with previous finding (Bernard and Lauwerys 1986; Lauwerys et al. 1994).

Table 2. Cadmium, calcium, and iron in blood and cadmium in urine by age

\begin{tabular}{ccccc}
\hline & \multicolumn{3}{c}{ Age (Years) } & Total \\
\cline { 2 - 4 } & $50-59$ & $60-69$ & $70+$ & \\
\hline Blood cadmium(ug/l) & & & & \\
$\mathrm{N}$ & 142 & 105 & 46 & 293 \\
Mean \pm Sd & $1.16 \pm 1.10$ & $1.18 \pm 0.89$ & $1.33 \pm 1.15$ & $1.19 \pm 1.04$ \\
Median & 0.8 & 0.88 & 0.92 & 0.84 \\
GM (GSD) & $0.78(0.96)$ & $0.87(0.85)$ & $0.93(0.89)$ & $0.83(0.91)$ \\
$5^{\text {th }}-95^{\text {th }}$ percentile & $0.13-3.35$ & $0.19-3.01$ & $0.27-3.62$ & $0.15-3.35$ \\
p-value & & & & 0.48 \\
& & & & \\
Urine cadmium (ug Cd/g cre) & 144 & 105 & 46 & 295 \\
N & $1.24 \pm 1.92$ & $1.44 \pm 1.47$ & $1.67 \pm 1.82$ & $1.38 \pm 1.76$ \\
Mean \pm Sd & 0.86 & 1.11 & 1.06 & 0.94 \\
Median & $0.74(1.05)$ & $0.91(1.06)$ & $0.92(1.21)$ & $0.82(1.08)$ \\
GM (GSD) & $0.10-3.32$ & $0.12-3.44$ & $0.09-5.96$ & $0.10-4.05$ \\
$5^{\text {th }}$-95 $5^{\text {th }}$ percentile & & & & 0.13 \\
p-value & & &
\end{tabular}

Blood calcium (mg/dL)

$\begin{array}{ccccc}\mathrm{N} & 144 & 104 & 46 & 294 \\ \text { Mean } \pm \text { Sd } & 9.04 \pm 0.37 & 9.06 \pm 0.36 & 9.07 \pm 0.40 & 9.05 \pm 0.37 \\ \text { Median } & 9.0 & 9.0 & 9.05 & 9.0 \\ \text { GM (GSD) } & 9.03(0.04) & 9.06(0.04) & 9.06(0.04) & 9.04(0.04) \\ 5^{\text {th }}-95^{\text {th }} \text { percentile } & 8.5-9.7 & 8.5-9.7 & 8.4-9.9 & 8.5-9.7 \\ \text { p-value } & & & & 0.75\end{array}$

Blood iron (mg/dL)

$\mathrm{n}$

$\operatorname{Mean} \pm$ Sd

Median

GM (GSD)

$5^{\text {th }}-95^{\text {th }}$ percentile
144

$116.15 \pm 41.64 \quad 108.85 \pm 36.71$

116.5

$108.06(0.40)$

107.5

$01.97(0.39)$

$57.0-190.0$

$56.0-168.0$
46

$99.37 \pm 29.70$

$110.90 \pm 38.6$

2

111.0

103.52

$53.0-177.0$

p-value: of Wilcoxon rank-sum test; $\mathrm{SD}$ : standard deviation; GM:geometric mean; GSD: geometric standard deviation. 
Table 3. The statistics for levels of cadmium in blood and urine by demographic characteristics

\begin{tabular}{|c|c|c|c|c|c|c|}
\hline & \multicolumn{3}{|c|}{ Blood cadmium (ug/L) } & \multicolumn{3}{|c|}{ Urine Cadmium (ug $\mathrm{Cd} / \mathrm{g}$ cre.) } \\
\hline & $\mathrm{n}$ & Median & GM (GSD) & $\mathrm{n}$ & Median & GM (GSD) \\
\hline \multicolumn{7}{|l|}{ Education (Years) } \\
\hline$\leqq 9$ & 142 & 0.98 & $0.96(0.91)$ & 143 & 1.05 & $0.91(1.02)$ \\
\hline $10-15$ & 82 & 0.79 & $0.76(0.91)$ & 83 & 0.85 & $0.74(1.16)$ \\
\hline$>15$ & 64 & 0.72 & $0.69(0.87)$ & 64 & 0.76 & $0.70(1.04)$ \\
\hline p-value* & 0.02 & & & 0.10 & & \\
\hline \multicolumn{7}{|l|}{ Occupation } \\
\hline White collar & 154 & 0.79 & $0.74(0.93)$ & 156 & 0.86 & $0.75(1.06)$ \\
\hline Blue collar & 67 & 1.04 & $1.05(0.82)$ & 67 & 1.05 & $0.84(1.07)$ \\
\hline Others & 62 & 0.83 & $0.83(0.93)$ & 72 & 1.10 & $0.89(1.06)$ \\
\hline p-value* & 0.047 & & & 0.38 & & \\
\hline \multicolumn{7}{|l|}{ Smoking } \\
\hline No & 139 & 0.66 & $0.73(0.94)$ & 139 & 0.80 & $0.71(1.03)$ \\
\hline Quit $>5$ years & 45 & 0.70 & $0.66(0.96)$ & 45 & 0.70 & $0.65(1.07)$ \\
\hline Quit $\leqq 5$ years & 26 & 1.16 & $1.09(0.54)$ & 27 & 1.18 & $0.93(1.06)$ \\
\hline Yes & 81 & 1.19 & $1.09(0.87)$ & 82 & 1.27 & $1.08(1.08)$ \\
\hline p-value* & 0.0002 & & & 0.004 & & \\
\hline \multicolumn{7}{|l|}{ Alcohol } \\
\hline No & 174 & 0.79 & $0.75(0.97)$ & 174 & 0.81 & $0.73(1.12)$ \\
\hline Quit & 25 & 1.00 & $0.93(0.93)$ & 25 & 1.00 & $0.62(1.29)$ \\
\hline Yes & 87 & 0.88 & $0.95(0.75)$ & 89 & 1.18 & $1.03(0.85)$ \\
\hline p-value* & 0.14 & & & 0.08 & & \\
\hline \multicolumn{7}{|l|}{ Fish and Shellfish } \\
\hline$<1$ (dish/week) & 35 & 0.88 & $0.88(0.95)$ & 35 & 0.86 & $0.65(1.23)$ \\
\hline $1-6$ & 196 & 0.79 & $0.77(0.87)$ & 198 & 0.9 & $0.78(1.01)$ \\
\hline$\geqq 7$ & 48 & 1.04 & $1.05(0.97)$ & 48 & 1.12 & $1.02(1.12)$ \\
\hline p-value* & 0.06 & & & 0.21 & & \\
\hline
\end{tabular}

Cre: : creatinine; ${ }^{*}$ p-value of Wilcoxon rank-sum test.

Table 4 also shows current smokers were 2.5 times more likely than nonsmoker to have higher cadmium level in urine. There was no risk to have $\mathrm{BCd}$ level $>0.84$ $\mathrm{ug} / \mathrm{L}$ for men who had quit smoking for longer than 5 Years. The risk with elevated $\mathrm{BCd}$ level was significant for active smokers $(\mathrm{OR}=3.2,95 \% \mathrm{CI}=1.7-6.2)$ or men who quit smoking not long enough $(\mathrm{OR}=5.3,95 \% \mathrm{CI}=1.9-14.7)$, reflecting smoking as the main source of current cadmium exposure.

In conclusion this study suggests that age had a stronger association with the level of urine cadmium than with the level of blood cadmium. Data also show that 
cigarette smoke inhalation is a more important exposure source of cadmium tha occupational exposure, and the intake of alcohol and fish/shell fish.

Table 4. Odds ratios (OR) and 95\% confidence intervals (CI) for subjects with blood cadmium $\geq 0.84 \mathrm{ug} / \mathrm{L}$ and urine cadmium $\geq 1.73 \mathrm{ug} \mathrm{Cd} / \mathrm{g}$ creatinine by associated factors obtained from multivariate logistic regression

\begin{tabular}{ccc}
\hline Factor & $\begin{array}{c}\text { Blood cadmium } \\
\text { OR }(95 \% \mathrm{CI})\end{array}$ & $\begin{array}{c}\text { Urine cadmium } \\
\text { OR }(95 \% \mathrm{CI})\end{array}$ \\
\hline Age $\quad$ (years $)$ & & \\
$50-59$ & 1.0 & 1.0 \\
$60-69$ & $1.2(0.7-2.3)$ & $2.0(1.0-4.0)$ \\
$70+$ & $2.0(0.9-4.8)$ & $3.4(1.3-8.8)$
\end{tabular}

Occupation

$\begin{array}{ccc}\text { White collar } & 1.0 & 1.0 \\ \text { Blue collar } & 1.2(0.6-2.3) & 1.0(0.5-2.2) \\ \text { Others } & 0.9(0.4-1.8) & 0.9(0.4-2.1)\end{array}$

Smoking

$\begin{array}{ccc}\text { No } & 1.0 & 1.0 \\ \text { Quit }>5 \text { years } & 1.0(0.5-2.2) & 0.5(0.2-1.5) \\ \text { Quit } \leqq 5 \text { years } & 5.3(1.9-14.7) & 1.5(0.5-4.2) \\ \text { Yes } & 3.2(1.7-6.2) & 2.5(1.2-5.1)\end{array}$

Alcohol

$\begin{array}{lll}\text { No } & 1.0 & 1.0 \\ \text { Quit } & 1.3(0.5-3.5) & 0.7(0.2-2.1) \\ \text { Yes } & 1.0(0.6-1.9) & 1.1(0.5-1.9)\end{array}$

Calcium in blood $(\mathrm{mg} / \mathrm{dL})$

$\begin{array}{lll}\leqq 9.0 & 1.0 & 1.0 \\ >9.0 & 1.1(0.7-1.9) & 2.0(1.1-3.6)\end{array}$

Iron in blood $(\mathrm{mg} / \mathrm{dL})$

$\begin{array}{lll}\leqq 110 & 1.0 & 1.0 \\ >110 & 0.9(0.5-1.5) & 1.1(0.6-2.1)\end{array}$

Fish and Shellfish ( dish/ week)

$\begin{array}{lll}<1 & 1.0 & 1.0 \\ 1-6 & 0.7(0.3-1.6) & 1.1(0.4-2.9) \\ \geqq 7 & 1.6(0.6-4.2) & 2.3(0.8-7.2)\end{array}$

Acknowledgment. This study was granted from MJ Health Center, Taipei, Taiwan. 


\section{REFERENCES}

American Cancer Society Cancer facts and figures-1999 (1999) Atlanta GA: American Cancer Society.

Black RJ, Bray F, Ferlay J, Parkin DM (1997) Cancer incidence and mortality in the European union: cancer registry data and estimates of national incidence for 1990. European J Cancer 33:1075-1107.

dell'Omo M, Muzi G, Piccinini R, Gambelunghe A, Morucci P, Fiordi T, Ambrogi M, Abbritti G. (1999) Blood cadmium concentrations in the general population of Umbria, central Italy. Sci Total Eniviron 226: 57-64.

Elghamy NA, Schumacher MC, Slattery ML, West DW, Lee JS (1990) occupation-al, cadmium exposure, and prostate cancer. Epidemiology 1:107-115.

Elinder CG (1992) Cadmium as an environmental hazard. IARC Sci Pub 118:123-132.

Flanagan PR,McLellan JS, Haist J, Cherian MG, Chamberlain MJ, Valberg LS (1978) Increased dietary cadmium absorption in mice and human subjects with iron deficiency. Gastroenterology 74:841-846.

Haas GP, Saker WA (1997) Epidemiology of prostate cancer. Cancer-A Cancer J Clin 47: 273-287.

Järup L, Berglund M, Elinder CG, Nordberg G, Vahter M (1998) Health effect of cadmium exposure- a review of the literature and a risk estimate. Scandinavian J Work Environ Health 24(suppl 1):1-52.

Klaassen CD (1996) Cadmium in Casarett \& Doull's Toxicology: The basic science of poisons, $5^{\text {th }}$ ed. McGraw-Hill, USA:699-702.

Lauwerys RR, Bernard AM, Roels HA, Buchet JP. (1994) Cadmium: exposure markers as predictors of nephrotoxic effects. Clin Chem 40:1391-1394.

Lee JS, White KL. (1980) A review of the health effects of cadmium. American J Ind Med 1:307-317.

Paschal DC, Burt V, caudill SP, Gunter EW, Pirkle JL, Sampson EJ, Miller DT, Jackson RJ (2000) Exposure of the U.S. population aged 6 and older to cadmium: 1988-1994. Arch Environ Contam Toxicol 38:377-83.

Pearce NE, Sheppard RA, Fraser J (1987) Case-control study of occupation and cancer of the prostate in New Zealand. J Epidemiol Community Health 41:130-132.

Samposon EJ (1999) Cadmium in Urine [NHANES]. Div Environmental Health Laboratory Sciences Nutritional Biochemistry Branch Method code 0360A. Centers for Disease Prevention and Control. Atlanta, GA

Sharma RP, Mckenzie JM, Kjellstrom T (1982) Analysis of submicrogramme levels of cadmium in whole blood, urine, and hair by graphite furnace atomic absorption spectroscopy. J Anal Toxicol 6:135-138

Sung JFC, Lin RS, Pu YS, Chen YC, Chang HC, Lai MK (1999) Risk factors for prostate carcinoma in Taiwan --A case-control study in a Chinese population. Cancer 86:484-491.

Waalkes MP, Rehm S (1994) Cadmium and Prostate Cancer. J Toxicol Environ Health 43:251-269.

Yen LL, Pan LY, Yen HW, Lee LA (1994) The smoking status in adults in Taiwan area: Prevalence rates and risk factors. Chinese J Pub Health 13:371-380. 